\title{
Population structure, distribution pattern and microhabitat characteristics of Aglaonema simplex in Pasatan Protected Forest, Jembrana, Bali, Indonesia
}

\author{
DEWI LESTARI ${ }^{\boldsymbol{\nu}}$, NI PUTU SRI ASIH \\ Bali Botanic Garden. Candikuning, Baturiti, Tabanan 82191, Bali, Indonesia. Tel.: +62-368-2033170, 2033170, Fax. +62-368-2033171 "email: \\ dewi016@lipi.go.id
}

Manuscript received: 11 July 2017. Revision accepted: 24 October 2017.

\begin{abstract}
Lestari D, Asih NPS. 2017. Population structure, distribution pattern and microhabitat characteristics of Aglaonema simplex in Pasatan Protected Forest, Jembrana, Bali, Indonesia. Biodiversitas 18: 1663-1668. Aglaonema simplex Blume is one species of Aglaonema that is distributed in Bali, Indonesia. This species can be found in the forests of Jembrana, Karangasem, Tabanan, Buleleng and Bangli. There is no recent data for A. simplex's population and microhabitat in Bali, while this data is needed to develop future conservation policy. By tracking populations over time, ecologists can see how these populations have changed and may be able to predict how they are likely to change in the future. Monitoring the size and structure of populations can also help ecologists to manage populations. This study was aimed to determine the current condition of $A$. simplex in the Pasatan forest and to find out the population structure, distribution, and its microhabitat characteristics. The study was conducted along two tracks at Pasatan Forest, Bali on June 911, 2015. Data were collected using the purposive quadrant plot method and analyzed descriptively, tabulated in tables and graphs. The population pattern distribution was as defined by standardized Morisita's index and microhabitat differences in both tracks were determined by the Mann-Whitney test in SPSS 16. The total number of A. simplex was 114 individuals. Thirty-seven percent of plants were juveniles, while $36 \%$ were mature plants without fruit and $27 \%$ were mature plants with fruit. The population structure along the first track was dominated by a mature population of plants without fruit, while fruiting mature plants dominated the structure of the population along the second track. The distribution of the population along the first track was clustered, while distribution along the second track was uniform. A. simplex was found at an altitude of $367-448 \mathrm{~m}$ asl., oil pH of $6.7-6.8$, soil humidity of $73 \%-84 \%$, air temperature $27^{\circ}-28^{\circ} \mathrm{C}$, air humidity at $80 \%-86 \%$, with low light intensity of $170-225$ lux.
\end{abstract}

Keywords: Aglaonema simplex, Jembrana, microhabitat characteristics, Pasatan protected forest, population

\section{INTRODUCTION}

Aglaonema is a genus of flowering plants in the arum family, Araceae, a monocot, herbaceous plants with fibrous roots. Leaf shape varied between oval, oblong or deltaloid and smooth leaf surface, hairless with various leaf tips. Position of the leaves are alternate or opposite with the stalk hugging the stem. As with other Araceae, Aglaonema inflorescence consists of two main parts, the spathe and spadix. The flowers are arranged on the spadix. At the top of the spadix, there are male flowers, with sterile flowers in the middle and female flowers at the base (Mayo et al. 1997).

All species of Aglaonema come from Southeast Asia, India, China, Indonesia and New Guinea (Nicolson 1969; Mayo et al. 1997; Allen 2011). This plant is known as Chinese evergreen (Antosh 2001). Aglaonema was first introduced to Europe at the Kew Botanic Gardens in 1885 and cultivated in the USA in 1930 (Chen et al. 2004). It soon became widespread and popular.

It is estimated that there are 22 species of Aglaonema in the world (Boyce et al. 2010). It can be found growing in primary or secondary forests, ravines and humid places. Yusof et al. (2013) said that this genus is also found in pyroclastic areas. A few species are restricted to kerangas or monsoonal perhumid semi-deciduous forest (Boyce and
Wong 2012). They are predominantly found at an altitude of less than 1500 meters above sea level (asl), although some species could be found at more than 2000 meters asl on Mount Kinabalu, such as Aglaonema simplex Blume (Nicolson 1969).

Aglaonema was favored as an indoor ornamental plant in Indonesia (Qodriyah and Sutisna 2007). Their varied and beautiful leaves attract more and more hobbyist. Soon, Aglaonema became popular and source of income for many farmers and was cultivated in many regions (Roza et al. 2012), but most of them are hybrids. Therefore, we have to explore more Aglaonema germplasm to conserve and develop it for wider purpose.

One of Aglaonema species distributed in Bali is Aglaonema simplex (Kurniawan and Asih 2012). This species can also be found in Sulawesi (Nugroho and Santika 2008), Southern Myanmar, Java (Central and East Java), Sumatra, Madura, Kalimantan, Sula Islands and part of the Philippines (Yuzammi 2000; Erlinawati 2010), Laos (Nguyen et al. 2014) and Malaysia (Mansor et al. 2012). In Bali, this species can be found in the forests of Jembrana (Hanum and Asih 2016), Karangasem (Asih et al. 2015), Tabanan, Buleleng and Bangli (Kurniawan and Asih 2012). According to Asih et al. (2014), A. simplex can be used as medicine to relieve fever and heal ulcers. 
Aglaonema simplex can reach $100 \mathrm{~cm}$ high, with a white-grey trunk. There are two variations of leaf morphology of $A$. simplex, a plain green leaf with a slightly wavy edge and a white patterned leaf with a flat edge (Winarti 2002). The leaves are elliptical to elongated, with a rounded leaf base, tapered leaf tips, primary leaf veins slightly prominent adaxially and prominent abaxially. Leaf sheaths can be found approximately $1 / 2-7 / 8$ length of the petiole. The spathe is yellowish-green or whitish-green when it first opens and during anthesis, it becomes more elongated. The length of the spadix is about $5-7 \mathrm{~cm}$ and the ripe fruit is red (Hanum and Asih 2016).

According to the IUCN, only 7 species that have been declared on IUCN Red List, from more than 600 spesies of Araceae that were estimated to be distributed in Indonesia. It means that Indonesia still needs many researches on ecology of Araceae. In IUCN, A. simplex is categorized as least concern, not too affected by forest destruction or degradation. However, the data is old, so more monitoring and data surveys are needed to update this data (Allen 2011). Tracking populations over time is needed to see how populations have changed and may be able to predict how they are likely to change in the future. Monitoring the size and structure of populations can also help ecologists to manage populations (Openstax 2017).

Actually, Araceae's ecology research in general have been held in West Kalimantan (Ilhamullah et al 2015) and Kelantan, Malaysia (Yusof et al 2013). However, this research did not state about $A$. simplex population and microhabitat characteristic, while this information is needed to understand its ecology and to establish its future conservation policy (Kusuma \& Astuti 2009). Therefore, this study is held in Pasatan protected forest, Bali, as one of distribution areas of $A$. simplex. The aim of this study was to determine the current condition of $A$. simplex in the Pasatan protected forest, to find out the population structure, distribution and its microhabitat condition.

\section{MATERIALS AND METHODS}

\section{Study area}

The study was conducted in Pasatan protected forest, Poh Santen, District Mendoyo, which is included in Tegalcangkring Resort Forest Management (RFM), on June 9-11, 2015. The area covers of 740 hectares, but some of them has been disturbed and converted into cultivated land, planted with bananas, coffee and cacao. However, there are some areas that have not been converted yet, and were still in virgin state, such as the top of the hill and the riverside. Therefore, we held this research in those virgin areas, i.e. the hill and riverside. There are two tracks that have been explored: the path to sumber air (riverside) and path to puncak (top of the hill). The first track was along the side of Pergung River from $346 \mathrm{~m}$ asl to $432 \mathrm{~m}$ asl. The second track was along the left side of Pergung River until it reached an elevation of $586 \mathrm{~m}$ asl where there were no $A$. simplex found.

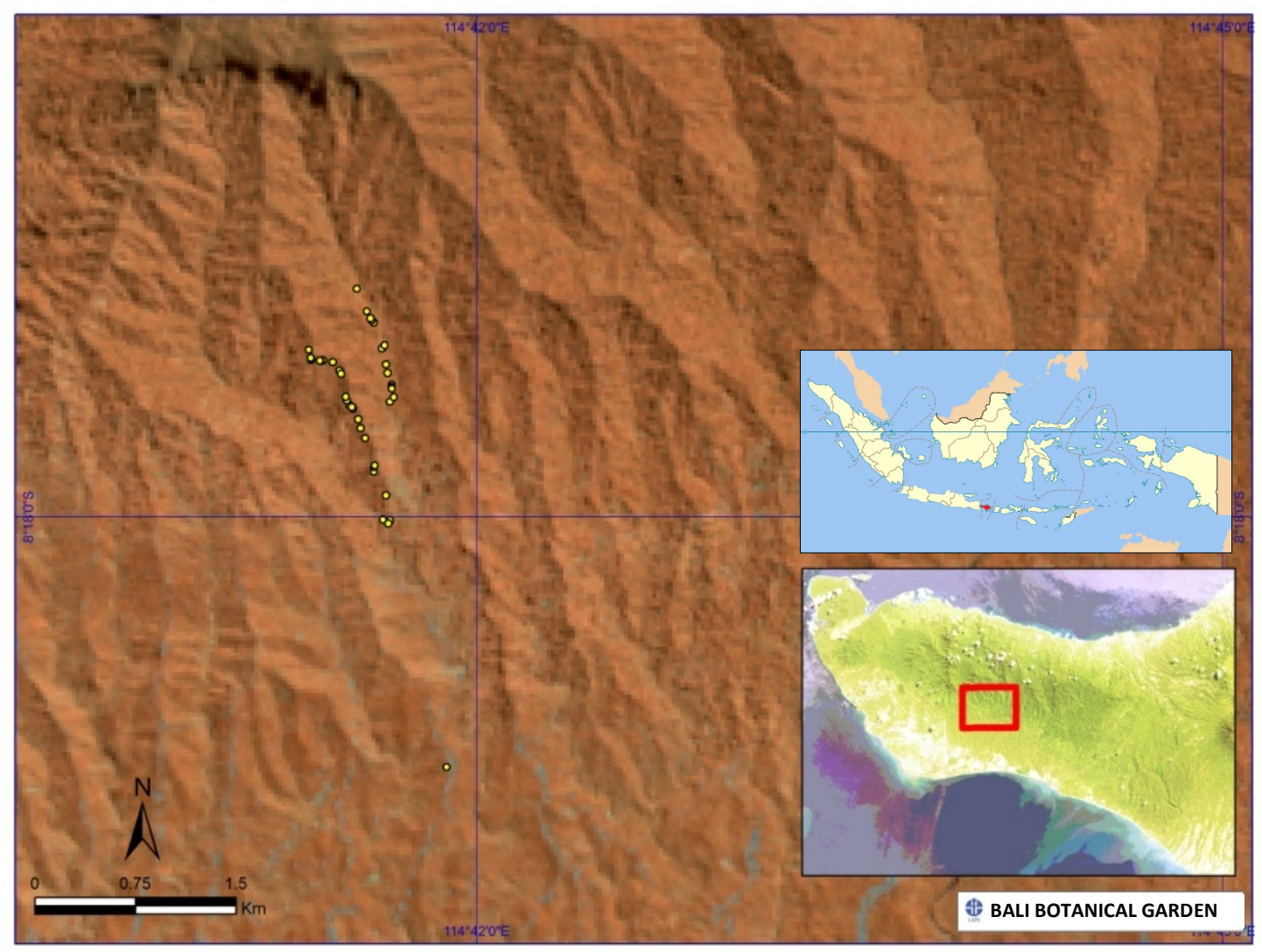

Figure 1. There were two tracks that were explored: the right is first track (a path to sumber air), while the left is second track (a path to puncak). Location of research in Pasatan Protected Forest, Jembrana, Bali, Indonesia 
The forest vegetation along the first track was moist with dense undergrowth. Trees were dominated by Sauraia sp. while plants that grow on the surface of the rocks (lithophytes) included Begonia coriacea and other Araceae genera such as Homalomena sp. Forests along the second track were dominated by trees from the Clusiaceae and Macadamia genera. Endemic climbers such as tiying-lut lut (Dinochloa sepang) were also found along this track.

\section{Procedures}

The data was collected purposively (purposive sampling). The quadrant plots of $2 \mathrm{~m} \times 2 \mathrm{~m}$ were made at each encounter of $A$. simplex. The parameters were the number of individuals that were found, $A$. simplex's stage of growth (juvenile, mature, fruiting/flowering mature) soil $\mathrm{pH}$, soil moisture, humidity, altitude, air temperature and light intensity. Juvenile was characterized by the presence of two leaves that were still attached to the stem. While mature was characterized by leaf that its clasps and encircle the stem and fruiting/flowering mature was characterized by the presence of fruit/flower (Nicolson 1969).

\section{Data analysis}

The data were analyzed descriptively and tabulated in graphs and tables. The population distribution pattern was defined by standardized Morisita's index to determine how the population was distributed: randomly, uniformly or clumped. The standardize of the Morisita index is used because this index is an improvement of the Morisita index, by placing an absolute scale between -1 and 1 . This index is also the best method for measuring the spatial distribution patterns because it does not depend on population density and sample size (Rani 2003). Standardized Morisita index (Ip) was calculated as follows:
When, $I_{d_{i}} \geq M_{c_{i}}>1, I_{p_{i}}=0.5+0.5 \times\left[\frac{I_{d_{i}}-M_{c_{i}}}{n-M_{c_{i}}}\right]$,

When, $M_{c_{i}}>I_{d_{i}} \geq 1, I_{p_{i}}=0.5 \times\left[\frac{I_{d_{i}}-1}{M_{u_{i}}-1}\right]$,

When, $1>I_{d_{i}}>M_{u_{i}}, I_{p_{i}}=-0.5 \times\left[\frac{I_{d_{i}}-1}{M_{u_{i}}-1}\right]$ and

When, $1>M_{u_{i}}>I_{d_{i}}, I_{p_{i}}=-0.5+0.5 \times\left[\frac{I_{d i}-M_{u i}}{M_{u_{i}}}\right]$,

Differences in microhabitat along both tracks were determined by non parametric statistical test, the MannWhitney test in SPSS 16, because microhabitat data were found to be uncommonly distributed. A significance value of $<0.05$ means that the hypothesis that two tracks did not differ significantly is rejected, whereas a significance value of $>0.05$ means that the hypothesis that two tracks did not differ significantly is accepted.

\section{RESULTS AND DISCUSSION}

\section{Results}

Aglaonema simplex was found to have green leaves and slightly wavy edges (Figure 2). Eight other Araceae species were also found, namely Alocasia longiloba, Amorphophallus muelleri, Amorphophallus sp., Amorphophallus variabilis, Homalomena sp., Rhaphidophora sp., Schismatoglottis calyptrata, and Scindapsus hederaceus. Over an elevation of $459 \mathrm{~m}$ asl, none of $A$. simplex was found, while Amorphophallus variabilis was found at a highest altitude, i.e. at $498 \mathrm{~m}$ asl.

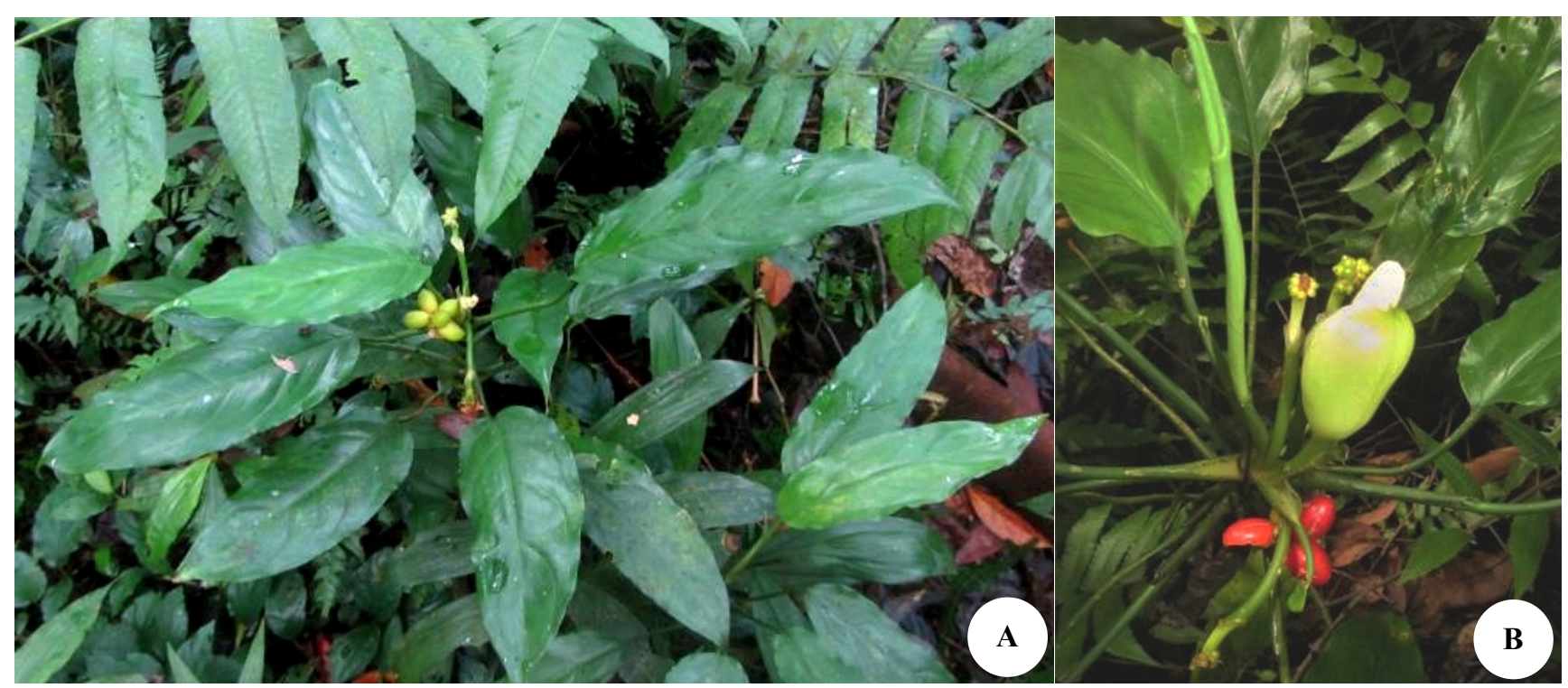

Figure 2.A. Aglaonema simplex leaf morphology with green leaves and curly edges; B. A. simplex inflorescence with cone and white spathe with ripe red fruit 


\section{Population structure}

Eighteen plots were observed on both tracks with 114 individuals of $A$. simplex in total. The population was predominantly found along the first track (74\%), while the remainder was found along the second track. Nevertheless, the average number of individuals per plot on each track did not differ significantly. This is demonstrated by the Mann-Whitney test that showed a significance value of $0.0583>0.005$. Similarly, the population density did not differ significantly (Table 1).

The population was dominated by juveniles (37\%) followed by mature plants without fruit $(36 \%)$ and fruiting mature plants $(27 \%)$. However, the structure of the population in both tracks was different (Figure 3). Figure 3 shows that the population structure along the first track was dominated by a mature population of plants without fruit, while the structure of the population along the second track was dominated by fruiting mature plants.

\section{Distribution pattern}

Standardized Morisita's index values for the first track was 0.50356 , so its distribution pattern was clumped, while the standardized Morisita's index along the second track was -0.50296 , so $A$. simplex in this track was dispersed uniformly. The distribution along both tracks is shown in Figure 4.

\section{Microhabitat condition}

In this study, $A$. simplex was found to live at an altitude of $367-448 \mathrm{~m}$ asl., with $\mathrm{pH}$ soil $6.7-6.8$, soil humidity at $73 \%-84 \%$, air temperature $27^{\circ}-28^{\circ} \mathrm{C}$, air humidity $80 \%$ $86 \%$, with a low light intensity of 170-225 lux (Table 2). The soil texture along the first track was top soil, black color, moist, porous with a little sandy. Soil texture in the second track was dominated by dried compacted soil, slightly clay with red color.

Table 1. Altitude, number of plots, average population and population density of Aglaonema simplex

\begin{tabular}{lcccc}
\hline Track & $\begin{array}{c}\text { Altitude } \\
\text { (m asl) }\end{array}$ & $\begin{array}{c}\text { Plot } \\
\text { nos. }\end{array}$ & $\begin{array}{c}\text { Average } \\
\text { population } \\
\text { (ind. } / \text { plot) }\end{array}$ & $\begin{array}{c}\text { Population } \\
\text { density }\end{array}$ \\
\hline Sumber air & $<400$ & 13 & 6.46 & 1.03 \\
Puncak & $>400$ & 5 & 6 & 0.96 \\
\hline
\end{tabular}

Table 2. Microhabitat condition of Aglaonema simplex in both track

\begin{tabular}{|c|c|c|c|}
\hline \multirow[b]{2}{*}{ Parameter } & \multicolumn{2}{|l|}{ Site } & \multirow{2}{*}{$\begin{array}{l}\text { Asymp } \\
\text { Sig (2- } \\
\text { tailed) }\end{array}$} \\
\hline & $\begin{array}{l}\text { Sumber air } \\
(\text { mean }+ \text { SE) }\end{array}$ & $\begin{array}{l}\text { Puncak } \\
(\text { mean + SE) }\end{array}$ & \\
\hline Altitude & $366.46 \pm 2.53$ & $448.2 \pm 7.92$ & 0.001 \\
\hline Soil pH & $6.73+0.28$ & $6.8 \pm 0.07$ & 0.605 \\
\hline Soil humidity & $83.46 \pm 8.49$ & $73 . \overline{23} \pm 9.67$ & 0.065 \\
\hline Temperature & $27.71 \pm 0.65$ & $26.9 \pm 0.19$ & 0.002 \\
\hline Air humidity & $85.95 \pm 2.29$ & $79.88 \pm 2.39$ & 0.003 \\
\hline Light intensity & $170.31 \pm 62.89$ & $225 \pm 26.96$ & 0.034 \\
\hline
\end{tabular}

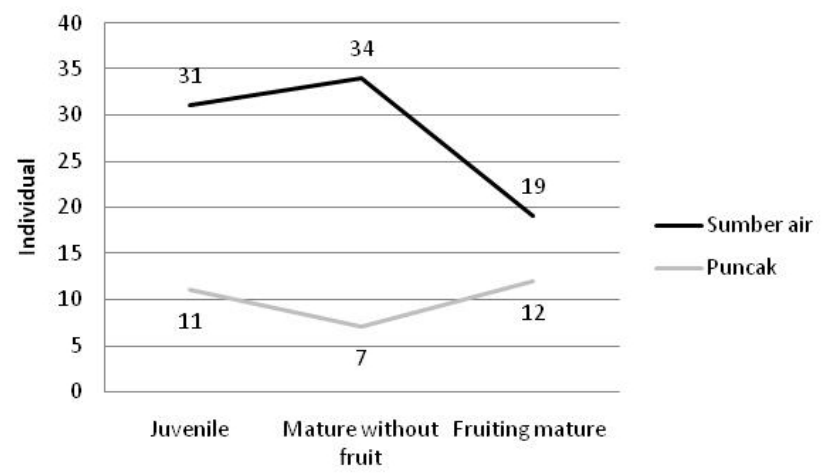

Figure 3. Population structure along both tracks

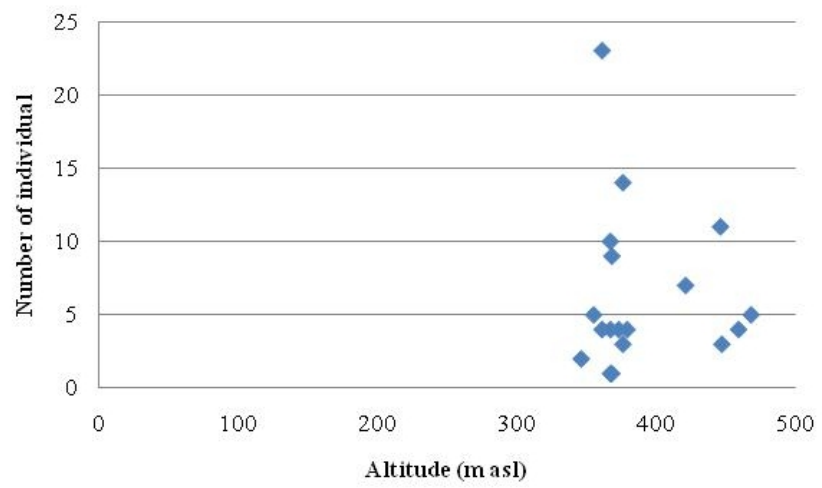

Figure 4. Population distribution of Aglaonema simplex

Mann-Whitney test show that there was a significant difference between altitude, humidity and temperature on both tracks, while soil moisture, soil pH and light intensity did not differ significantly.

\section{Discussion}

The population was predominantly found along the first track $(74 \%)$, while the remainder was found along the second track. It is thought to be related to their microhabitat. Budiarto (2006) stated that the important factor for Aglaonema growth is light, temperature, humidity and air circulation. Aglaonema generally thrives in places with limited lighting, like in the shade of large trees, although it also needs sunlight for photosynthesis to occur. To grow optimally, it needs temperatures of $30^{\circ} \mathrm{C}$ during the day and $23^{\circ} \mathrm{C}$ at night with $50-60 \%$ humidity (Djojokusuma 2006). This plant also likes porous soil so that air circulates well and water flows smoothly (Antosh 2001). The air temperature along the first track was close to the ideal temperature of $A$. simplex as mentioned above, its light intensity was also lower and its soil was more porous than media at the second track. So, the microhabitat at the first track was better for the growth of $A$. simplex than the second track. 
The population was dominated by juveniles. Similar results was obtained by Kusuma and Astuti (2009) that the population was supported by many numbers of juveniles. This condition indicates satisfactory regeneration behavior (Saxena and Singh 1985; Bharati and Prasad 2015).

Figure 3 shows that there were differences in population structure between the two tracks. The number of fruiting mature plants along the second track was more than the number of mature plants without fruit, while along the first track, mature plants without fruit was more than the number of fruiting mature plants. This was due to the different light intensity. The light intensity at the second track was higher (Table 2), enabling a higher amount of photosynthesis to occur, so that A. simplex along the second track grow faster and achieve the reproductive stage faster than A. simplex along the first track. As Shibao et al (2005) said that photosynthesis and reproduction of Cyripedium flavum are affected by light availability in the under-storey, higher photosynthetic rate increases reproductive success and fitness of $C$. flavum. Widiatuti et al. (2004) also said that there was interaction effect of light intensities on relative growth rate of Chrysanthemum.

Plants of the same species may have a different distribution pattern because it depends on other factors in the habitat such as seed predators, seed spreading agent and seedling pathogens (Russo and Augspurger 2004). It also happens to $A$. simplex in Pasatan protected forest. $A$. simplex along the first track was clustered and along the second track was distributed uniformly. Plant distribution is usually affected by the seed spreading agent. Plants distributed in groups usually do not have an agent so seedlings only grow around the parent, while plants randomly distributed usually have agents that enable seeds to grow away from the parent (Howe 1989). Seeds of $A$. simplex are not spread by water (Mansor et al. 2012). Its large size does not allow it to move away so juveniles only grow around the parent. A lot of water and nutrients along the first track encouraged individuals to grow into large groups. Along the second track, some pieces of $A$. simplex seed - broken by a bird were found, so it is suspected that seeds are also spread by birds but not widely dispersed. They did not reproduce in large groups because the supply of water and nutrients along the second track was not as much as the first track. The second track was away from the river and consisted of compacted soil, not as porous as growing media along the first track. This was a limitation for individuals to grow in large groups. This condition supports Kleiner (2016) statement that uniform distribution usually happens because of something that prevents individuals to live in close proximity to each other, such as competition for light, nutrients, and water or because their roots are allelopathic.

Nonparametric statistical test - Mann-Whitney determined that there was a significant difference between altitude, humidity, and temperature on both tracks, but the average population and the population density did not differ significantly. So, it is assumed that A. simplex can tolerate the differences of altitude, humidity and temperature.

\section{ACKNOWLEDGEMENTS}

Thanks go to the Head of KPH Bali Barat who gave permission to acquire the data, I Gusti Sudirga who helped to collect the data and Rajif Iryadi who helped to make the research location map. This activity was done with funds from the 2015 fiscal year of Bali Botanic Garden, from sub-activities: Araceae conservation in Kalimantan.

\section{REFERENCES}

Antosh G. 2001. Success with Your Aglaonema Indoor: Free Plant Care Tips. GHA, Florida.

Allen DJ. 2011. Aglaonema simplex. The IUCN Red List of Threatened Species 2011. www.iucnredlist.org/pdflink.8902274. Downloaded on 23 November 2016

Asih NPS, Warseno T, Kurniawan A. 2014. Medicinal Araceae in Eka Karya Bali Botanical Garden. In: Setyawan AD, Sugiyarto, Pitoyo A, Hernawan UE, Sutomo, Widyastuti A (eds). Study, Use and Conservation of Archipelago Biodiversity in Health Sector; Proceeding of National Seminary on Biodiversity. Sebelas Maret University, Surakarta, 9 November 2013. [Indonesian].

Asih NPS, Warseno T, Kurniawan A. 2015. Araceae inventory studies on Mount Seraya (Lempuyang), Karangasem, Bali. Pros Sem Nas Masy Biodiv Indon 1: 521-527. [Indonesian].

Bharati S, Prasad AGD. 2015. Regeneration status of tree composition in the sacred groves of Mercara, Central Western Ghats. Eur J Exp Biol 5 (10): 29-40.

Boyce PC, Wong SY, Jen ATP, Eng LS, Ling LS, Kiaw NK, Bin OI. 2010. The Araceae of Borneo: The Genera. Aroideana 33: 3-73.

Boyce PC, Wong SY. 2012. The Araceae of Malesia I: Introduction. Malayan Nat J 64 (1): 33-67.

Budiarto K. 2006. Recognize Aglaonema and How to Breed it. IOCRI, Cianjur.

Chen J, Devanand PS, Norman DJ, Henny RJ, Chao CCT. 2004. Genetic relationships of Aglaonema species and cultivars inferred from AFLP markers. Annals of Botany 93: 157-166.

Djojokusuma P. 2006. Spectacular Aglaonema. Agromedia Pustaka, Jakarta.

Erlinawati I. 2010. Araceae Biodiversity arround Wilis Mt, East Java. Berkala Penelitian Hayati Edisi Khusus 4A: 13-17.

Hanum SF, Asih NPS. 2016. Eksplorasi jenis-jenis Araceae di Bukit Mesehe, Kabupaten Jembrana. Proceeding of $2^{\text {nd }}$ Biosains National Seminar of Biology Empowerment as a Basic Science to Support Technology and Sains Development. Udayana University, Denpasar, 19-20 November 2015. [Indonesian].

Howe HF. 1989. Scatter and clump dispersal and seedling demography: hypothesis and implications. Oecologia 79: 417-426.

Ilhamullah B, W Ekyastuti, H Husni. 2015. The potential study of down and epiphytes plant as ornamental plants in PPTAT Dian Tama Area West Borneo. Jurnal Hutan Lestari 3 (3): 481-487.

Kleiner K. 2016. Plant Population Pattern. Ecology Spring: 1-8. http: //goose.ycp.edu/ kkleiner/ecology/elabs/lab3_dispersion_S11.pdf.

Kurniawan A, Asih NPS. 2012. Araceae of Bali Island. LIPI PRESS, Jakarta.

Kusuma YWC, Astuti IP. 2009. Population and microhabitat characteristic of Homalomena bellula Schott in Mount Slamet, Central Java, Indonesia. Biodiversitas 10: 201-205.

Mayo, Bogner SJJ, Boyce PC. 1997. The Genera of Araceae. Belgium Royal Botanical Gardens, Kew.

Mansor M, Boyce PC, Othman AS, Sulaiman B. 2012. The Araceae of Peninsular Malaysia. Penerbit Universiti Sains Malaysia, Pulau Pinang.

Nguyen DX, Nguyen NX, Nguyen DD, Dinh TH, Le DT, Dinh DH. 2014. Distribution and habitat of the Laotian Rock Rat Laonastes aenigmamus Jenkins, Kilpatrick, Robinson \& Timmins, 2005 (Rodentia: Diatomyidae) in Vietnam. Biodiv Data J 2: e418. DOI: 10.3897/BDJ.2.e4188

Nicolson DH. 1969. A Revision of The Genus Aglaonema (Araceae). Smithsonian Institution Press, Washington. 
Nugroho BTA, Santika Y. 2008. Exploration and inventory of Araceae genera in Silui Mountain and Uluisimbone forest, Kolaka Regency, South-East Sulawesi. Biodiversitas 9 (4): 288-291.

Openstax Rice University. 2017. Population Demography. Download the original article for free at http: //cnx.org/contents/185cbf87-c72e48f5-b51e-f14f21b5eabd@10.12.

Qadriyah L, Sutisna A. 2007. Vegetative breeding techniques of some accession of Aglaonema using single bud stem cutting. Buletin Teknik Pertanian 12(2): 74-77.

Rani C. 2003. Measurement Method and Diperssion Pattern Analysis of Bentics Organism. Jurnal Protein 19: 1351-1368.

Roza S, Suryani P, Sunarlim M. 2012. Production Efficiency Factor of sri rejeki (Aglaonema comutatum) in Pekanbaru. Jurnal Agroteknologi 3 (1): $35-44$.

Russo SE, Augspurger CK. 2004. Aggregated seed dispersal by spider monkeys limits recruitment to clumped patterns in Virola calophylla. Ecol Lett 7: 1058-1067.
Saxena AK, Singh JS. 1985. Tree population structure of certain Himalayan forest association and implications concerning their future composition. Vegetatio 58: 61-69.

Shibao Z, Hu H, Zhou Z, Xu K, Yan N, Li S. 2005. Photosynthesis in relation to reproductive success of Cypripedium flavum. Ann Bot 96: 43-49.

Widiastuti L, Tohari, Sulistyaningsih E. 2004. The Effect of light intensities and daminozide concentrations on the microclimate and the growth of potted chrysanthemum. Ilmu Pertanian 11 (2): 35-42.

Winarti. 2002. Aglaonema simplex Blume (Araceae) in Java Island. [Thesis]. Institut Pertanian Bogor, Bogor. [Indonesian].

Yusof NYB, Hamzah Z, Kayat F, Zulhisyam AK. 2013. Assessment on Diversity and Abundance of Araceae in Limestone and Pyroclastics Areas in Gua Musang, Kelantan, Malaysia. J Trop Resour Sustain Sci 1 (1): 16-24.

Yuzammi, 2000. A Taxonomic Revision of the Terrestrial and Aquatic Aroids (Araceae) in Java. [Thesis]. University of New South Wales, Australia. 